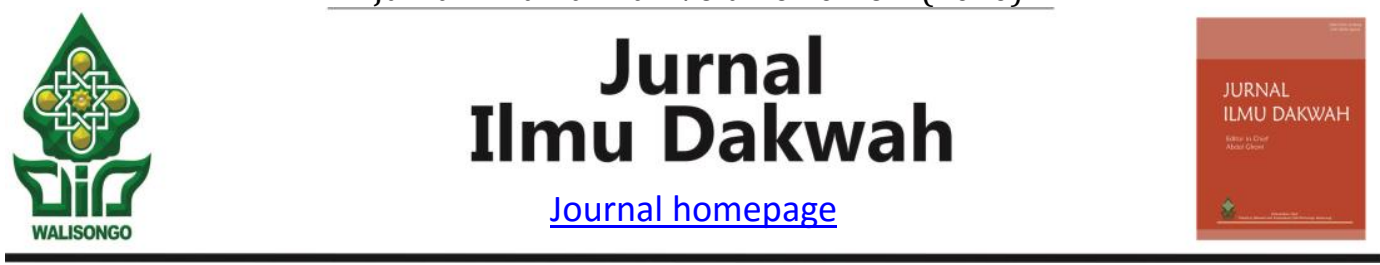

\title{
PERAN LEMBAGA KARYA MASYARAKAT MANDIRI DOMPET DHUAFA DALAM PENGELOLAAN ZAKAT UNTUK KEMANDIRIAN PENERIMA MANFAAT PROGRAM
}

\author{
Muhtadi \\ Universitas Islam Negeri Syarif Hidayatullah Jakarta \\ email: muhtadi@uinjkt.ac.id
}

\begin{abstract}
This research is about the role of the Dompet Dhuafa Independent Community Work Institute on the independence of program beneficiaries in the process of community empowerment in the productive economy based on zakat. This research approach is quantitative with survey methods. Variable X is the role of the Independent Work Society Institute and the Y variable is behavior change for the independence of program beneficiaries. The results of this study show that the role of the Independent Community Work Institutions (the role of the facilitator, the role of educators and the technical role) of behavior change is close to $40 \%$. This is indicated by the results of the SPSS determination coefficient (R2) of 0.382. This effect is very significant (significant) as indicated by the probability $0.00^{* *}$. The influence of the role of the Independent Community Works Institution is very significant for behavioral change for the independence of program beneficiaries.
\end{abstract}

Keywords: zakat, dompet dhuafa.

\begin{abstract}
Abstrak
Penelitian ini mengenai peran Lembaga Karya Masyarakat Mandiri Dompet Dhuafa terhadap kemandirian penerima manfaat program pada proses pemberdayaan masyarakat di bidang ekonomi produktif berbasis zakat. Pendekatan penelitian ini adalah kuantitatif dengan metode survei. Variabel X adalah peran Lembaga Karya Masyaraka Mandiri dan variabel $\mathrm{Y}$ perubahan perilaku untuk kemandirian penerima manfaat program. Hasil dari penelitian ini bahwa Peran Lembaga Karya Masyarakat Mandiri (peran fasilitator, peran pendidik dan peran teknis) terhadap perubahan perilaku hampir mendekati $40 \%$. Hal ini ditunjukkan dengan hasil SPSS koefisien determinasi $\left(\mathrm{R}^{2}\right)$ sebesar 0,382 . Pengaruh ini sangat nyata (signifikan) yang ditunjukkan dengan probabilitas $0,00^{* *}$. Pengaruh peran Lembaga Karya Masyarakat Mandiri sangat nyata bagi perubahan perilaku untuk kemandirian penerima manfaat program.
\end{abstract}

Kata kunci: zakat, dompet dhuafa. 


\section{PENDAHULUAN}

Dalam pengelolaan zakat memerlukan suatu organisasi atau lembaga yaitu BAZ dan LAZ. Sebagaimana termaktub dalam Undang Undang nomor 23 tahun 2011 tentang Pengelolaan Zakat bahwa terdapat dua lembaga yang memiliki hak mengelola zakat, yaitu Badan Amil Zakat (BAZ) yang dikelola pemerintah dan Lembaga Amil Zakat (LAZ). Keberadaan lembaga pengelola zakat agar proses pemungutan dan penyaluran zakat dapat dilaksanakan secara maksimal dan optimal untuk kesejahteran para mustahik. Dalam konteks ini, pengelolaan zakat tidak cukup diserahkan pada kebaikan dari para muzakki.

Pengelolaan zakat oleh lembaga bertujuan antara lain: pertama, membangun dan mengembangkan kesadaran para muzakki sesuai norma agama. Kedua, meningkatkan kinerja lembaga keagamaan lebih dioptimalkan untuk mewujudkan kesejahteraan penerima manfaat. Ketiga, optimalisasi manfaat dari zakat. Program-program pemberdayaan masyarakat memafaatkan dana zakat ditujukan untuk meningkatkan kesejahteraan dan kualitas kehidupan mustahiq tersebut sehingga ada perubahan status dari penerima berubah menjadi pemberi zakat (Hasan, 2011: 71).

Dalam konteks di atas, lembaga pengelola zakat memiliki peranan penting agar pengumpulan dan pemanfaatan/pendayagunaan zakat akan lebih optimal dalam meningkatkan para mustahik. Lembaga pengelola ZIS dapat melaksanakan kegiatan pemberdayaan masyarakat pemberdayaan pada bina ekonomi, sosial, dan fisik. Lembaga ini yang melaksanakan program-program pemberdayaan di bidang kesehatan, ekonomi produktif, sosial dan lain sebagainya.

Di sisi lain, pemberdayaan masyarakat di bidang ekonomi produktif yang sumber pendanaannya dari zakat belum melahirkan perubahan perilaku yang signifikan pada penerima manfaatnya. Hal ini berimplikasi pada belum munculnya perilaku-perilaku yang positif dari penerima manfaatnya. Program dan kegiatan lebih menekankan pada bantuan teknis sementara perubahan-perubahan perilaku yang seharusnya dapat secara bersamaan belum dapat diwujudkan. Misalnya, program pemberdayaan masyarakat di bidang ekonomi produktif masih belum secara optimal menumbuhkan kemandirian bagi penerima manfaat program.

Keberlanjutan usaha dan kemandirian belum tumbuh pada penerima manfaat program dari kegiatanya pemberdayaan masyarakat di bidang ekonomi produktif disebabkan; Pertama, sumber daya manusia belum trampil dan kompeten; kedua, nilai besaran pinjaman dan frekuensi pemberian dana bergulir. Ketiga, pemasaran yang belum optimal. Pemasaran produk atau jasa dari peneriman manfaat akan menjadi langkah untuk keberlanjutan program. Keempat, peningkatan kompetensi dan kapasitas penerima manfaat, kelima fasilitator kurang kompeten atau proses pendampingan terbatas, keenam, sarana dan prasarana yang kurang mndukung untuk proses pemberdayaan.

Pada kaitan ini, lembaga-lembaga pengelola zakat untuk memberdayakan ekonomi umat dapat melakukan peran-peran yang dapat memandirikan penerima manfaat program. Peran lembaga itu berupa fasilitasi, pendidikan, representasi dan teknis. Peranperan ini dapat dioptimalkan dalam rangka memandirikan penerima manfaat program, pada tahap selanjutnya mereka dari mustahik dapat menjadi muzakki. Lembaga Karya Masyarakat Mandiri telah melaksanakan peran-peran tersebut untuk memandirikan penerima manfaat program.

Kegiatan pemberdayaan masyarakat dengan pendanaan dari zakat masih dominan pada teknis; pemberian bantuan permodalan, pemberian pelatihan, pembuatan sarana dan prasarana, belum maksimal pada perubahan pada aspek kemandirian. Padahal output dari proses pemberdayaan dalam berbagai bidang baik pendidikan, ekonomi, kesehatan maupu lingkungan adalah kemandirian. Hasil dari proses kemandirian penerima manfaat yang belum tercapai menjadi menarik untuk dikaji lebih lanjut. Untuk permasalahan 
penelitiannya adalah bagaimana pengaruh peranKarya Masyarakat Mandiri Dompet Dhuafa terhadap kemandirian penerima manfaat program pada proses pemberdayaan masyarakat di bidang ekonomi produktif berbasis zakat.

\section{KAJIAN TEORI \\ Pemberdayaan Masyarakat}

Menurut Paul (dalam Suparjan \& Hempri, 2003:43), bahwa pemberdayaan adalah pengalihan kekuasaan berkeadilan pada mereka yang kurang beruntung meningkatkan kesadaran politis dan kekuasaan kelompok yang lemah serta memperbesar pengaruh mereka terhadap proses dan hasil-hasil pembangunan. Suparjan (2003: 43), pengertian pemberdayaan masyarakat mengandung arti, yaitu: to give ability or enable to, yaitu upaya untuk meningkatkan kemampuan masyarakat melalui pelaksaan berbagai kebijakan dan program-program pembangunan, agar kondisi kehidupan masyarakat mencapai kesejahteraannya.

Menurut Sumaryadi (2005: 114), pemberdayaan masyarakat merupakan upaya meningkatkan harkat dan martabat masyarakat dan pribadi manusia. Proses peningkatan dapat dilaksanakan dengan pemberian motivasi, penguatan kompetensi dan kapasitas untuk lebih berdaya dalam kehidupannya. Menurut John and Peggy Hucthison (1993: 4) bahwa pemberdayaan adalah

"Empowerment is a social-action process that promotes participation of people, organization, and communities toward the goals of increased individual and community control, political efficacy,improved quality of community life, and social justice".

Menurut Pranarka dalam (Sedamaryanti, (1996: 27) konsep pemberdayaan mempunyai makna yaitu:

"menekankan pada proses menstimulasi, mendorong dan memotivasi individu agar mempunyai kemampuan atau daya untuk menentukan apa yang menjadi pilihan hidupnya. Pemberdayaan kepada kelompok atau perorangan harus mengetahui kekuatan, kelemahandan kondisi lingkungan mereka, sehingga apa yang harus ditingkatkan dan didorong menjadi jelas."

Pemberdayaan menunjuk pada kemampuan orang, khususnya kelompok rentan dan lemah, untuk (a) memiliki akses terhadap sumber-sumber produktif yang memungkinkan mereka dapat meningkatkan pendapatannya dan memperoleh barang-barang dan jasajasa yang mereka perlukan; dan (b) berpartisipasi dalam proses pembangunan dan keputusan-keputusan yang mempengaruhi mereka. (c). Penguatan potensi kelompok rentan untuk berdaya dalam peningkatan kualitas kehidupannya.

\section{Zakat Sebagai Sistem Kesejahteraan}

Dalam Undang-undang Nomor 23 tahun 2011 pada pasal 4 ayat 1, harta yang wajib dikenakan zakat maal meliputi: (1) emas, perak, dan logam mulia lainnya; (2) uang dan surat berharga lainnya; (3) perniagaan; (4) pertanian, perkebunan dan kehutanan; (5) peternakan dan perikanan; (6) pertambangan; (7) perindustrian; (8) pendapatan dan jasa; dan (9) rikaz.

Sebagai pilar ketiga dalam perekonomian, zakat memiliki fungsi yang sangat penting dalam pertumbuhan ekonomi (Qur'an surah Ar-Rum ayat 39). Ini tercermin pada dua konsep utama, yaitu pertumbuhan ekonomi berkeadilan dan mekanisme sharing dalam perekonomian (Qur'an surah Adz-Dzariyat ayat 19). Tujuan utamanya adalah para mustahiq dapat meningkatkan kesejahteraannya. Output dari penyaluran zakat bahwa para mustahiq dapat diselesaikan kebutuhan hidupnya. Outcome dari penyaluran zakat mewujudkan ketahanan ekonomi para mustahiq (Indonesia Zakat \& Development Report, 2011). 
Dalam sistem ekonomi Islam, zakat memiliki fungsi penyaluran modal atau kekayaan kepada mereka yang kurang beruntung. Dimana menurut (Nasution 2006, 48) Zakat adalah salah satu instrumen yang efektif untuk pengentasan kemiskinan daripada instrumen fiskal konvensional karena pertama, target atau penerima zakat telah ditentukan secara jelas dan tegas. (Surah At Taubah: 60). Kedua, Zakat memiliki tarif yang tetap dan tidak berubah-ubah. Ketiga, Zakat memiliki tarif yang berbeda untuk tiap jenis harta yang berbeda, dan memberikan keringanan bagi usaha yang memiliki tingkat kesulitan produksi yang lebih tinggi. Ketiga, Zakat dikenakan pada cakupan yang luas dan merangkum berbagai aktivitas perekonomian, misalnya zakat penghasilan, pertambangan, perternakan, perkebunan. Kelima, zakat adalah merupakan pajak spiritual yang wajib dibayar oleh seorang muslimdalam kondisi apapun, karena itu penerimaan zakat cenderung stabil

Zakat itu adalah bagian dari institusi keuangan syariah. Karena institusi syariah itu mengenal ada dua institusi; pertama, Islamic finance public, yang terdiri dari Baitul Mal, Ad Diwan dan AL Hisbah. Kedua, Islamic Social Finance yang terdiri dari Institusi Amil Zakat dan Nadzir Wakaf. Secara makro, zakat memiliki implikasi ekonomi terhadap efisiensi alokatif, penciptaan lapangan pekerjaan, pertumbuhan ekonomi, stabilitas makro ekonomi, distribusi pendapatan, pengentasan kemiskinan dan jaring pengaman sosial (Indonesia Zakat \& Development Report, 2009). Dilihat dari sisi manfaat dan potensinya zakat juga dapat dijadikan modal dalam membangun bangsa terutama untuk peningkatan taraf hidup masyarakat dan sebagai sumber dana bagi penyediaan infrastruktur atau fasilitas umum.

\section{Pengelolaan Zakat}

Dalam pengelolaan zakat ada dua pendekatan; pertama, konsumtif. Pengelolaan dana zakat itu untuk kepentingan di bidang kesehatan, pemberian sembilan bahan pokok, pendidikan misalnya pemberian beasiswa dan sosial (bencana alam, pemberian konsumsi untuk orang-orang miskin dan lain-lain). Kedua, produktif. Pengelolaan dana zakat untuk kegiatan produktif adalah pengembangan dan pemberdayaan UMKM dan komunitas. Sebagaimana terlihat pada diagram di bawah ini.

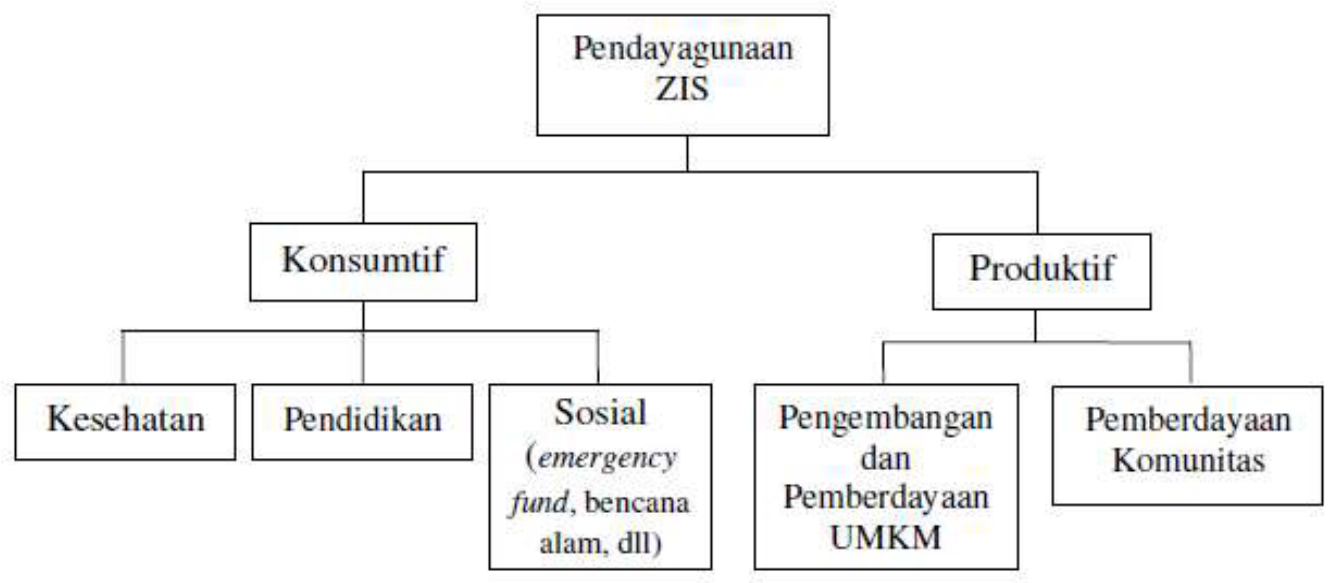

Sumber: Nasution et al., 2008.

\section{Peran LAZIS}

LAZIS yang juga merupakan salah satu lembaga ekonomi Islam yang bergerak bagi pengembangan ekonomi rakyat, Lembaga ini memiliki dua sisi kegiatan yaitu mendistribusikan dana secara konsumtif dan secara produktif. Secara konsumtif berarti dana zakat habis begitu saja dipergunakan untuk keperluan sehari-hari dan membiayai kesehatan. Secara produktif berarti mengembangkan usaha-usaha produktif memberikan 
bantuan dana modal untuk wirausaha dalam rangka meningkatkan kualitas income per capita pengusaha.. Pada perkembangannya, LAZIS tidak hanya menjadi lembaga penerima dan menyalur dana zakat, infak dan shadaqah, namun juga menjadi lembaga keuangan yang melakukan kegiatan untuk dana kemanusiaan, kesehatan, bantuan beasiswa dan lain-lain.

Berkaitan dengan peran LAZIS dalam pemberdayaan masyarakat mengacu pada apa yang dikemukakan oleh (Jim Ife, 2008, 558-609) sebagai berikut; Pertama, peranan fasilitatif lembaga adalah peranan yang dilakukan untuk membangkitkan semangat, motivasi atau memberi dorongan kepada masyarakat yang kurang beruntung untuk meningkatkan produktivitas dan pengelolaan usaha secara efisien. Kedua, peranan pendidikan lembaga yaitu peranan dalam rangka peningkatan pengetahuan, keterampilan serta pengalaman bagi individu-individu, kelompok-kelompok dan masyarakat. Ketiga, peranan representasional lembaga yaitu melakukan interaksi dengan badan-badan di masyarakat yang bertujuan bagi kepentingan individu-individu, kelompok-kelompok dan masyarakat. Peranan ini dilakukan, antara lain dengan : mendapatkan sumber-sumber dari luar tetapi dengan berbagai pertimbangan yang matang, seperti bantuan modal usaha, pelatihan pengembangan potensi dan produktivitas dari berbagai donator. Melakukan advokasi untuk membela kepentingan-kepentingan individu-individu, kelompokkelompok dan masyarakat seperti mendukung upaya implementasi program dan berupaya merealisasikan program tersebut. Keempat, peranan teknis lembaga melakukan pengumpulan dan analisis data, kemampuan menggunakan komputer, kemampuan melakukan presentasi secara verbal maupun tertulis, manajemen terhadap pengembangan potensi individu-individu, kelompok-kelompok dan masyarakat.

\section{Kemandirian Penerima Manfaat Program}

Menurut Desmita (Rachiwanti dan Hartosujono, 2015: 23) mendefinisikan bahwa "Kemandirian adalah kondisi dimana seseorang memiliki hasrat untuk maju demi kebaikan diriya sendiri, mampu mengambil keputusan dan inisiatif untuk mengatasi masalah serta kepercayaan diri dan bertanggung jawab atas apa yang dilakukannya" Definisi kemandirian lainnya juga dikemukakan oleh Andreas Nugroho (Susanto, 2018: 96) bahwa "Kemandirian menunjukan kepada adanya kepercayaan akan kemampuan diri untuk menyelesaikan persoalan-persoalan tanpa bantuan khusus dari orang lain".

Untuk kemandirian penerima manfaat program seperti pada memberikan pengertian kemandirian usaha pengrajin sebagai kemampuan pengrajin dalam kegiatan produksi, permodalan, dan pemasaran yang tidak tersubordinasi dengan pihak lain serta kerjasama dengan individu, kelompok atau organisasi untuk mencapai kemajuan bersama. Kemampuan ini mencakup ranah pengetahuan (kognitive), sikap (affective), dan keterampilan (psikomotorict). Berdasarkan hal tersebut, indikator kemandirian penerima manfaat adalah kapasitas untuk kerjasama, kapasitas untuk mengambil keputusan secara mandiri dan kapasitas berkaloborasi (Utami, 2007)

\section{METODE}

Jenis penelitian ini adalah penelitian explanatory research. Penelitian menerangkan (explanatory) merupakan penelitian survei yang bertujuan untuk pengujian hipotesis penelitian yang telah dirumuskan berdasarkan penjelasan dari pengaruh antar peubah (Singarimbun dan Effendi, (2011:5) . Riset ini berlokasi di Cianjur Jawa Barat dan waktu pelaksanaannya pada Juni-September 2019. Populasinya adalah kelompok sasaran penerima manfaat program pemberdayaan masyarakat ekonomi produktif bidang pertanian. Sumber data yang sudah terkumpul adalah data-data sekunder seperti jumlah penerima manfaat program, visi dan misi program serta output program. Data primer dikumpulkam melalui kuesioner. 
Populasi penelitian adalah penerima manfaat program pemberdayaan masyarakat ekonomi produktif bidang pertanian yang dilaksanakan oleh Karya Masyarakat Mandiri. Jumlah populasi penerima program pemberdayaan ekonomi produktif di Kabupaten Cianjur berjumlah 230. Dalam pengambilan sampel menggunakan teknik probability sampling yaitu lebih dikhususkan pada teknik random sampling, teknik ini dilakukan secara acak atau dipilih secara acak, setiap unsur pada populasi harus memiliki kesempatan yang sama untuk dapat dipilih menjadi sampel. Untuk itu penarikan sampel dalam penelitian ini memakai rumus Slovin dalam Sevilla et al. (1993) sebagai berikut:

$$
\mathrm{n}=\mathrm{N}
$$

dimana:

$\mathrm{n}=$ ukuran sampel

$\mathrm{N}=$ ukuran populasi

e 2 = nilai kritis (batas ketelitian) $5 \%$

Penentuan jumlah sampel menggunakan perhitungan dengan kesalahan $5 \%$, sehingga ukuran sampel yang harus diambil adalah sebesar 85 penerima manfaat program.

Pengumpulan data primer dan sekunder dalam penelitian ini menggunakan instrumen yakni; pertama, kuesioner. Berupa pertanyaan tertutup dan terbuka yang diajukan kepada responden yang sudah disusun dan ditata dengan sistematis. Kedua, FGD (Focus Group Discussion atau Diskusi Kelompok Terfokus) dengan tokoh masyarakat, pengelola dan pelaksana program dengan menggunakan kuesioner yang berbentuk pertanyaan terbuka.

\section{HASIL DAN PEMBAHASAN}

\section{Lokasi Penelitian}

Kabupaten Cianjur secara geografis terletak pada koordinat 1060 42'- 1070 25' Bujur Timur dan 60 21'-70 25' Lintang Selatan, dengan ketinggian 7-2.962 mdpl dan memiliki kemiringan 0-40\%. Batas-batas wilayah daerah meliputi; Sebelah utara berbatasan dengan Kabupaten Bogor dan Kabupaten Purwakarta ; Sebelah timur berbatasan dengan Kabupaten Purwakarta, Kabupaten Bandung, Kabupaten Bandung Barat dan Kabupaten Garut; Sebelah selatan berbatasan dengan Samudra Hindia; Sebelah barat berbatasan dengan Kabupaten Sukabumi.

Wilayah Kabupaten Cianjur terdiri dari 32 kecamatan dengan luas wilayah 361.434,98 ha dan kecamatan yang memiliki wilayah terluas adalah kecamatan Cidaun dengan luas 29.551,23 ha. Jumlah penduduk Kabupaten Cianjur tahun 2016 diperkirakan sebanyak 2.256.589 jiwa yang terdiri dari 1.160 .520 jiwa laki-laki dan 1.096 .069 jiwa perempuan. Sex ratio sebesar 105,88, yang artinya terdapat 105 atau 106 penduduk laki-laki pada setiap 100 penduduk perempuan..

Luas tanam padi di Kabupaten Cianjur tahun 2016 mencapai 161.892,2 ha, terluas berada di Kecamatan Sindang barang yaitu 9.660,1 ha, diikuti Kecamatan Kadupandak dan Pagelaranya itu masing-masing 9.457,5 ha dan 9.085,2 ha. Sementara itu, luas panen padi di Kabupaten Cianjur mencapai 165.451,3 ha. Pada tahun 2017 populasi ternak besar yaitu sapi potong sebanyak 38.374 ekor, sapi perah berjumlah 2.438 ekor, dan populasi kerbau mencapai 8.016 ekor. Produksi daging mencapai 51.5 juta kg, meningkat dibandingkan tahun sebelumnya 49,4juta kg. Produksi daging terbanyak ada di Kecamatan Gekbrong yaitu sekitar 15 juta kg. Sementara produksi telur mencapai 21,7juta kg, terbanyak dari Kecamatan Haurwangi yaitu 6,3 juta kg. Produksi susu sebanyak 5,8juta kg, paling banyak ada di Kecamatan Sukaresmi yaitu 1,9 juta kg. Produksi ikan air tawar mencapai $120.594,27$ ton dan paling banyak ada di wilayah Kecamatan Karang tengah dan 
Kecamatan Ciranjang. Produksi ikan di perairan umum mencapai 1.968.273,28 kg, hanya ada di wilayah Kecamatan Mande, Cikalong kulon, Ciranjang, Haurwangi, dan Sukaluyu. Produksi ikan tambak dan laut mencapai 1.753,16 ton, hanya ada di 3 kecamatan karena wilayah ini ada sekitar laut selatanya itu kecamatan Agrabinta, Sindang barang, dan Cidaun.

\section{Profil Karya Masyarakat Mandiri (KMM)}

Karya Masyarakat Mandiri (KMM) dengan nama awal Program Pengembangan Kemandirian Masyarakat (P2KM), dimulai sejak tahun 2000 hingga 2005, merupakan program Dompet Dhuafa yang berperan dalam pemberdayaan masyarakat bidang ekonomi yang diharapkan mampu swadaya dalam pengelolaannya secara berkelanjutan dan memberikan manfaat secara langsung bagi masyarakat yang tidak berdaya. Selanjutnya berubah menjadi Karya Masyarakat Mandiri sejak tahun 2012. Selanjutnya dilakukan merger pada tahun 2016 antara Pertanian Sehat Indonesia (PSI), Kampoeng Ternak Nusantara (KTN) dan Karya Masyarakat Mandiri dengan tetap menggunakan nama Karya Masyarakat Mandiri (KMM). KMM merupakan organ PT CE Dompet Dhuafa dalam pengembangan program-program ekonomi komunitas melalui aktifitas pemberdayaan masyarakat. Jenis Program yakni pertanian, peternakan, UMKM, Pesisir dan Nelayan serta CSR.

\section{Peran Fasilitator}

Peran fasilitator memberikan motivasi untuk sadar berusaha memiliki rata-rata 3,44 pada pertanyaan X2.1.1 yang berarti responden setuju terhadap pernyataan tersebut. Peran fasilitator memberikan motivasi pemilihan kegiatan usaha memiliki rata-rata 3,46 pada pertanyaan X2.1.2 yang berarti responden setuju terhadap pernyataan tersebut. Peran fasilitator memberikan motivasi pengelolaan usaha yang tekun dan pantang menyerah memiliki rata-rata 3,50 pada pertanyaan X2.1.3 yang berarti responden sangat setuju terhadap pernyataan tersebut. Peran fasilitator memberikan kesempatan pengelolaan usaha mandiri memiliki rata-rata 3,47 pada pertanyaan X2.1.4 yang berarti responden setuju terhadap pernyataan tersebut. Peran fasilitator memberikan kesempatan pemilihan jenis usaha memiliki rata-rata 3,43 pada pertanyaan X2.1.5 yang berarti responden setuju terhadap pernyataan tersebut.

Peran fasilitator memberikan dukungan untuk kegiatan usaha sesuai dengan kemampuan penerima manfaat program memiliki rata-rata 3,43 pada pertanyaan X2.1.6 yang berarti responden setuju terhadap pernyataan tersebut. Peran fasilitator memberikan dukungan pencarian informasi usaha memiliki rata-rata 3,40 pada pertanyaan X2.1.7 yang berarti responden setuju terhadap pernyataan tersebut. Peran fasilitator memberikan dukungan pencarian bahan baku produksi memiliki rata-rata 3,43 pada pertanyaan X2.1.8 yang berarti responden setuju terhadap pernyataan tersebut. Peran fasilitator membangun kelompok bersama untuk kegiatan usaha memiliki rata-rata 3,40 pada pertanyaan X2.1.9 yang berarti responden setuju terhadap pernyataan tersebut.

Peran fasilitator menggerakan penerima manfaat program untuk berwirausaha yang jujur memiliki rata-rata 3,41 pada pertanyaan X2.1.10 yang berarti responden setuju terhadap pernyataan tersebut. Peran fasilitator melakukan pemanfaatan sumberdaya dimiliki penerima manfaat program untuk kegiatan usaha memiliki rata-rata 3,39 pada pertanyaan X2.1.11 yang berarti responden setuju terhadap pernyataan tersebut. Peran fasilitator melakukan pemanfaatan sumberdaya dimiliki penerima manfaat program untuk kegiatan pengelolaan usaha memiliki rata-rata 3,40 pada pertanyaan X2.1.12 yang berarti responden setuju terhadap pernyataan tersebut. Sebagaimana dapat dilihat dalam tabel; 01 di bawah ini 
Tabel 1. Peran Fasilitator

\begin{tabular}{cccccc}
\hline Indikator & $\mathrm{N}$ & Minimum & Maximum & Mean & Std. Deviation \\
\hline $\mathrm{X} 2.1 .1$ & 70 & 3 & 4 & 3,44 &, 500 \\
\hline $\mathrm{X} 2.1 .2$ & 70 & 2 & 4 & 3,46 &, 530 \\
\hline $\mathrm{X} 2.1 .3$ & 70 & 3 & 4 & 3,50 &, 504 \\
\hline $\mathrm{X} 2.1 .4$ & 70 & 3 & 4 & 3,47 &, 503 \\
\hline $\mathrm{X} 2.1 .5$ & 70 & 2 & 4 & 3,43 &, 527 \\
\hline $\mathrm{X} 2.1 .6$ & 70 & 3 & 4 & 3,43 &, 498 \\
\hline $\mathrm{X} 2.1 .7$ & 70 & 3 & 4 & 3,40 &, 493 \\
\hline $\mathrm{X} 2.1 .8$ & 70 & 3 & 4 & 3,43 &, 498 \\
\hline $\mathrm{X} 2.1 .9$ & 70 & 3 & 4 & 3,40 &, 493 \\
\hline X2.1.10 & 70 & 3 & 4 & 3,41 &, 496 \\
\hline $\mathrm{X} 2.1 .11$ & 70 & 3 & 4 & 3,39 &, 490 \\
\hline X2.1.12 & 70 & 3 & 4 & 3,40 &, 493 \\
\hline Valid N (listwise) & 70 & & & & \\
\hline
\end{tabular}

\section{Peran Pendidik}

Peran Lembaga Karya Masyarakat Mandiri memberikan wawasan pengetahuan tentang usaha di bidang produksi memiliki rata-rata 3,47 pada pertanyaan k2.2.1 yang berarti responden setuju terhadap pernyataan tersebut. Peran Lembaga Karya Masyarakat Mandiri memberikan wawasan pengetahuan tentang modal usaha memiliki rata-rata 3,34 pada pertanyaan k2.2.2 yang berarti responden setuju terhadap pernyataan tersebut. Peran Lembaga Karya Masyarakat Mandiri memberikan informasi tentang kemitraan usaha memiliki rata-rata 3,35 pada pertanyaan k2.2.3 yang berarti responden setuju terhadap pernyataan tersebut.

Peran Lembaga Karya Masyarakat Mandiri memberikan informasi tentang promosi usaha memiliki rata-rata 3,39 pada pertanyaan k2.2.4 yang berarti responden setuju terhadap pernyataan tersebut. Peran Lembaga Karya Masyarakat Mandiri memberikan informasi tentang pemasaran usaha memiliki rata-rata 3,51 pada pertanyaan k2.2.5 yang berarti responden sangat setuju terhadap pernyataan tersebut. Peran Lembaga Karya Masyarakat Mandiri memberikan informasi tentang promosi usaha melaksanakan penyelenggaraan pelatihan tentang usaha memiliki rata-rata 3,53 pada pertanyaan k2.2.6 yang berarti responden sangat setuju terhadap pernyataan tersebut. Peran Lembaga Karya Masyarakat Mandiri melaksanakan penyelenggaraan pelatihan tentang promosi dan pemasaran memiliki rata-rata 3,33 pada pertanyaan k2.2.7 yang berarti responden setuju terhadap pernyataan tersebut.

Tabel 2. Peran Pendidik

\begin{tabular}{cccccc}
\hline Indikator & $\mathrm{N}$ & Minimum & Maximum & Mean & Std. Deviation \\
\hline $\mathrm{k} 2.2 .1$ & 70 & 3 & 4 & 3,47 & 0,503 \\
\hline $\mathrm{k} 2.2 .2$ & 56 & 2 & 4 & 3,34 & 0,549 \\
\hline $\mathrm{k} 2.2 .3$ & 69 & 3 & 4 & 3,35 & 0,480 \\
\hline $\mathrm{k} 2.2 .4$ & 69 & 3 & 4 & 3,39 & 0,492 \\
\hline $\mathrm{k} 2.2 .5$ & 70 & 3 & 4 & 3,51 & 0,503 \\
\hline $\mathrm{k} 2.2 .6$ & 70 & 3 & 4 & 3,53 & 0,503 \\
\hline $\mathrm{k} 2.2 .7$ & 70 & 2 & 4 & 3,33 & 0,503 \\
\hline Valid N (listwise) & 54 & & & & \\
\hline
\end{tabular}




\section{Peran Teknis}

Peran Lembaga Karya Masyarakat Mandiri memberikan modal usaha memiliki ratarata 3,37 pada pertanyaan k2.3.1 yang berarti responden setuju terhadap pernyataan tersebut. Peran Lembaga Karya Masyarakat Mandiri memberkan peralatan-peralatan usaha memiliki rata-rata 3,44 pada pertanyaan k2.3.2 yang berarti responden setuju terhadap pernyataan tersebut. Peran Lembaga Karya Masyarakat Mandiri memberikan bimbingan teknis memiliki rata-rata 3,40 pada pertanyaan k2.3.3 yang berarti responden setuju terhadap pernyataan tersebut.

Peran Lembaga Karya Masyarakat Mandiri memberikan bibit-bibit padi atau sayuran memiliki rata-rata 3,39 pada pertanyaan k2.3.4 yang berarti responden setuju terhadap pernyataan tersebut. Peran Lembaga Karya Masyarakat Mandiri memberikan bantuan pemasaran produ kmemiliki rata-rata 3,46 pada pertanyaan k2.3.5 yang berarti responden setuju terhadap pernyataan tersebut. Peran Lembaga Karya Masyarakat Mandiri memberikan bantuan promosi produk memiliki rata-rata 3,44 pada pertanyaan $\mathrm{k}$ 2.3.6 yang berarti responden setuju terhadap pernyataan tersebut

Tabel 3. Peran Teknis

\begin{tabular}{cccccc}
\hline Indikator & $\mathrm{N}$ & Minimum & Maximum & Mean & Std. Deviation \\
\hline $\mathrm{k} 2.3 .1$ & 70 & 2 & 4 & 3,37 & 0,516 \\
\hline $\mathrm{k} 2.3 .2$ & 70 & 3 & 4 & 3,44 & 0,500 \\
\hline $\mathrm{k} 2.3 .3$ & 70 & 2 & 4 & 3,40 & 0,522 \\
\hline $\mathrm{k} 2.3 .4$ & 70 & 2 & 4 & 3,39 & 0,519 \\
\hline $\mathrm{k} 2.3 .5$ & 52 & 3 & 4 & 3,46 & 0,503 \\
\hline $\mathrm{k} 2.3 .6$ & 70 & 3 & 4 & 3,44 & 0,500 \\
\hline Valid N (listwise) & 52 & & & & \\
\hline
\end{tabular}

\section{Aspek Pengetahuan untuk Kemandirian Penerima Manfaat Program.}

Peran pengetahuan tentang pengelolaan usaha memiliki rata-rata 3,41 pada pertanyaan k3.1.1 yang berarti responden setuju terhadap pernyataan tersebut. Peran pengetahuan tentang pemilihan usaha yang menguntungkan memiliki rata-rata 3,43 pada pertanyaan k3.1.2 yang berarti responden setuju terhadap pernyataan tersebut. Peran pengetahuan cara melakukan produksi yang efektif dan benar memiliki rata-rata 3,42 pada pertanyaan k3.1.3 yang berarti responden setuju terhadap pernyataan tersebut. Peran pengetahuan tentang kemitraan usaha memiliki rata-rata 3,39 pada pertanyaan k3.1.4 yang berarti responden setuju terhadap pernyataan tersebut.Peran pengetahuan tentang promosi dan pemasaran usaha memiliki rata-rata 3,36 pada pertanyaan k3.1.5 yang berarti responden setuju terhadap pernyataan tersebut.

Tabel 4. Aspek Pengetahuan

\begin{tabular}{cccccc}
\hline Indikator & $\mathrm{N}$ & Minimum & Maximum & Mean & Std. Deviation \\
\hline $\mathrm{k} 3.1 .1$ & 70 & 2 & 4 & 3,41 &, 577 \\
\hline $\mathrm{k} 3.1 .2$ & 70 & 2 & 4 & 3,43 &, 527 \\
\hline $\mathrm{k} 3.1 .3$ & 69 & 3 & 4 & 3,42 &, 497 \\
\hline
\end{tabular}




\begin{tabular}{cccccc}
\hline Indikator & $\mathrm{N}$ & Minimum & Maximum & Mean & Std. Deviation \\
\hline $\mathrm{k} 3.1 .4$ & 70 & 2 & 4 & 3,39 &, 519 \\
\hline k3.1.5 & 70 & 2 & 4 & 3,36 &, 539 \\
\hline Valid N (listwise) & 69 & & & & \\
\hline
\end{tabular}

\section{Aspek Sikap untuk Kemandirian Penerima Manfaat Progran}

Peran sikap mengelolau saha yang jujur dan benar memiliki rata-rata 3,50 pada pertanyaan k3.2.1 yang berarti responden sangat setuju terhadap pernyataan tersebut.Peran sikap berminat dalam kegiatan usaha memiliki rata-rata 3,47 pada pertanyaan k3.2.2 yang berarti responden setuju terhadap pernyataan tersebut. Peran sikap melakukan proses produksi yang baik dan benar memiliki rata-rata 3,44 pada pertanyaan k3.2.3 yang berarti responden setuju terhadap pernyataan tersebut. Peran sikap melakukan kemitraan usaha memiliki rata-rata 3,42 pada pertanyaan k3.2.4 yang berarti responden setuju terhadap pernyataan tersebut. Peran sikap melakukan promosi dan pemasaran usaha memiliki rata-rata 3,42 pada pertanyaan k3.2.5 yang berarti responden setuju terhadap pernyataan tersebut.

Tabel 5. Aspek Sikap

\begin{tabular}{cccccc}
\hline Indikator & $\mathrm{N}$ & Minimum & Maximum & Mean & Std. Deviation \\
\hline $\mathrm{k} 3.2 .1$ & 70 & 3 & 4 & 3,50 &, 504 \\
\hline $\mathrm{k} 3.2 .2$ & 70 & 3 & 4 & 3,47 &, 503 \\
\hline $\mathrm{k} 3.2 .3$ & 70 & 3 & 4 & 3,44 &, 500 \\
\hline $\mathrm{k} 3.2 .4$ & 69 & 3 & 4 & 3,42 &, 497 \\
\hline $\mathrm{k} 3.2 .5$ & 69 & 3 & 4 & 3,42 &, 497 \\
\hline Valid N (listwise) & 68 & & & & \\
\hline
\end{tabular}

\section{Aspek Ketrampilan untuk Kemandirian Penerima Manfaat Progran}

Peran keterampilan melakukan usaha yang sesuai keinginan memiliki rata-rata 3,29 pada pertanyaan k3.3.1 yang berarti responden setuju terhadap pernyataan tersebut.Peran keterampilan dapat meningkatkan pendapatan usaha memiliki rata-rata 3,40 pada pertanyaan k3.3.2 yang berarti responden setuju terhadap pernyataan tersebut. Peran keterampilan dapat meningkatkan keuntungan usaha memiliki rata-rata 3,4 pada pertanyaan k3.3.3 yang berarti responden setuju terhadap pernyataan tersebut. Peran keterampilan dapat meningkatkan omzet usaha memiliki rata-rata 3,37 pada pertanyaan k3.3.4 yang berarti responden setuju terhadap pernyataan tersebut. Peran keterampilan dapat melakukan investasi usaha memiliki rata-rata 3,40 pada pertanyaan k3.3.5 yang berarti responden setuju terhadap pernyataan tersebut.

Tabel 6. Aspek Ketrampilan

\begin{tabular}{cccccc}
\hline Indikator & $\mathrm{N}$ & Minimum & Maximum & Mean & Std. Deviation \\
\hline $\mathrm{k} 3.3 .1$ & 70 & 2 & 4 & 3,29 &, 542 \\
\hline $\mathrm{k} 3.3 .2$ & 70 & 2 & 4 & 3,40 &, 522 \\
\hline $\mathrm{k} 3.3 .3$ & 70 & 2 & 4 & 3,41 &, 551 \\
\hline
\end{tabular}




\begin{tabular}{cccccc}
\hline $\mathrm{k} 3.3 .4$ & 70 & 3 & 4 & 3,37 &, 487 \\
\hline $\mathrm{k} 3.3 .5$ & 70 & 3 & 4 & 3,40 &, 493 \\
\hline Valid N (listwise) & 70 & & & & \\
\hline
\end{tabular}

\section{Hubungan antara Peran LKMM dan Kemandirian Penerima Manfaat}

Dari analisis korelasi terdapat adanya hubungan antara variabel peran Lembaga Karya Masyarakat Mandiri (LKMM) terhadap variabel kemandirian penerima manfaat yang ada di wilayah Cianjur. Sebab nilai signifikannya tidak lebih besar dari 0,05 dan nilai $r$ nya sebesar $0,618^{* *}$ serta ada dua bintangnya ini menunjukkan memperkuat terjadinya korelasi baik dari variabel peran LKMM terhadap variabel kemandirian penerima manfaat dengan jumlah responden yaitu 70 .

Dengan demikian, bahwa peran-pera yang dilakukan Lembaga Karya Masyarakat Mandiri (KMM) Dhompet Dhuafa yakni; Pertama, peran fasilitator, peran pendidikan dan teknis telah berhasil dan berpengaruh nyata untuk kemandirian penerima manfaat program. Penerima manfaat program telah mampu dan termotivasi untuk mengambil keputusan dalam rangka pemilihan usaha untuk peningkatan pendapatan. Penerima manfaat telah berhasil mendapatkan penghasilan atau pendapatan untuk kesejahtearan mereka. Penerima manfaat dalam hal ini adalah para petani padi dan hortikultura yang diberikan bantuan oleh Lembaga karya masyarakat mandiri ini telah berhasil menolong dirinya sendiri untuk berdaya dan sejahtera.

Lembaga Karya Masyarakat Mandiri melalui tenaga fasilitator di lokasi pemberdayaan telah melakukan serangkaian kegiatan pemberian motivasi untuk usaha mereka. Fasilitator di lapangan telah terus menerus memberikan nasihat dan motivasi untuk tekun dan bekerja keras dalam berusaha. Mekanisme pemberian motivasi dan nasihat ini dilakukan baik secara formal maupun informal. Pemberian motivasi melalui forum formal yang rutin dilakukan yang dihadiri oleh penerima manfaat program bersama dengan fasilitator Lembaga Karya Masyarakat Mandiri. Sedangkan kegiatan informal dilakukan setiap bertemu dengan penerima manfaat program dilakukan bincang-bincang santai perihal kegiatan usaha, pemilihan bibit dan cara bertanam dan lainnya.

Kedua, peran pendidikan lembaga adalah peran dalam rangka peningkatan pengetahuan, keterampilan serta pengalaman bagi individu-individu, kelompok-kelompok dan masyarakat. Peran ini dilakukan oleh Lembaga Karya Masyarakat Mandiri Dhompet Dhuafa memberikan pelatihan tentang proses produksi dan cara bertanam, kepemimpinan dan pengetahuan tentang bibit.

Ketiga, peran representasional lembaga adalah melakukan interaksi dengan badanbadan di masyarakat yang bertujuan bagi kepentingan individu-individu, kelompokkelompok dan masyarakat. Peranan ini dilakukan, antara lain dengan: mendapatkan sumber-sumber dari luar tetapi dengan berbagai pertimbangan yang matang, seperti bantuan modal usaha, pelatihan pengembangan potensi dan produktivitas dari berbagai donatur. Melakukan advokasi untuk membela kepentingan-kepentingan individu-individu, kelompok-kelompok dan masyarakat seperti mendukung upaya implementasi program dan berupaya merealisasikan program tersebut. Peranan ini belum dilakukan oleh Lembaga Karya Masyarakat Mandiri Dhompet Dhuafa karena adanya beragam keterbatasan dari pendanaan maupun jaringan yang dimilikinya.

Keempat, peranan teknis lembaga melakukan pengumpulan dan analisis data, kemampuan menggunakan komputer, kemampuan melakukan presentasi secara verbal maupun tertulis, manajemen terhadap pengembangan potensi individu-individu, kelompok-kelompok dan masyarakat. Peran ini dilakukan oleh Lembaga Karya Masyarakat Mandiri Dhompet Dhuafa memberikan bibit, peralatan dan sarana yang diperlukan untuk kegiatan pemberdayaan ekonomi produktif, 
Tabel 7. Hasil Uji Korelasi Peran LKMM dan Kemandirian Penerima Manfaat

\begin{tabular}{llrr}
\hline & & Peran LKMM & Perilaku \\
\hline Peran LKMM & Pearson & 1 &, $618^{* *}$ \\
& Correlation & &, 000 \\
\cline { 2 - 4 } & Sig. (2-tailed) & 70 & 70 \\
\cline { 2 - 4 } Perilaku & Pearson &, $618^{* *}$ & 1 \\
& Correlation &, 000 & 70 \\
\cline { 2 - 4 } & Sig. (2-tailed) & 70 & \\
\cline { 2 - 4 } & $\mathrm{N}$ & & \\
\hline
\end{tabular}

**. Correlation is significant at the 0.01 level (2-tailed).

\section{Pengaruh Peran LKMM dan Kemnadirian Penerima Manfaat}

Pengaruh parsial peran fasilitator terhadap kemandirian penerima manfaat hampir mendekati $25 \%$. Hal ini ditunjukkan dengan hasil SPSS koefisien determinasi $\left(\mathrm{R}^{2}\right)$ sebesar 0,245 . Pengaruh parsial ini sangat nyata (signifikan) yang ditunjukkan dengan probabilitas $0,00^{* *}$. Pengaruh parsial peran pendidik terhadap kemandirian penerima manfaat sebesar $28,6 \%$. Hal ini ditunjukkan dengan hasil SPSS koefisien determinasi $\left(\mathrm{R}^{2}\right)$ sebesar 0,286. Pengaruh parsial ini sangat nyata (signifikan) yang ditunjukkan dengan probabilitas $0,00^{* *}$.

Pengaruh parsial peran teknis terhadap kemandirian penerima manfaat sebesar 19,6\%. Hal ini ditunjukkan dengan hasil SPSS koefisien determinasi $\left(\mathrm{R}^{2}\right)$ sebesar 0,196. Pengaruh parsial ini sangat nyata (signifikan) yang ditunjukkan dengan probabilitas $0,00^{* *}$. Adapun terdapat pengaruh simultan peran Lembaga Karya Masyarakat Mandiri (peran fasilitator, peran pendidik dan peran teknis) terhadap perubahan perilaku hampir mendekati $40 \%$. Hal ini ditunjukkan dengan hasil SPSS koefisien determinasi $\left(\mathrm{R}^{2}\right)$ sebesar 0,382 . Pengaruh sangat nyata (signifikan) yang ditunjukkan dengan probabilitas $0,00^{* *}$. Peran Lembaga Karyawan Masyarakat Mandiri memiliki kontribusi yang cukup tinggi pada perubahan perilaku karena mereka merasa bahwa peran fasilitator, pendidik, dan teknis telah memberikan pengaruh melalui pengetahuan, sikap dan keterampilan untuk kemandirian penerima manfaat program..

Secara lebih rinci dapat dilihat pada gambar 1. yang menunjukkan pengaruh secara parsial dan simultan dari variabel peran Lembaga Karya Masyarakat Mandiri dari peran fasilitator, pendidikan, terhadap perubahan perilaku yakni mewujudkan kemandirian penerima manfaat program yang mampu memilih jenis usaha, peningkatan pendapatan dan kesejahteraan, kemampuuan membangun mitra usaha dan kemampuan untuk mengembangkan jaringan promosi dan pemasaran dengan berbagai pihak, agar kegiatan yang dilakukan para petani padi dan holtikultura ini berkelanjutan. 


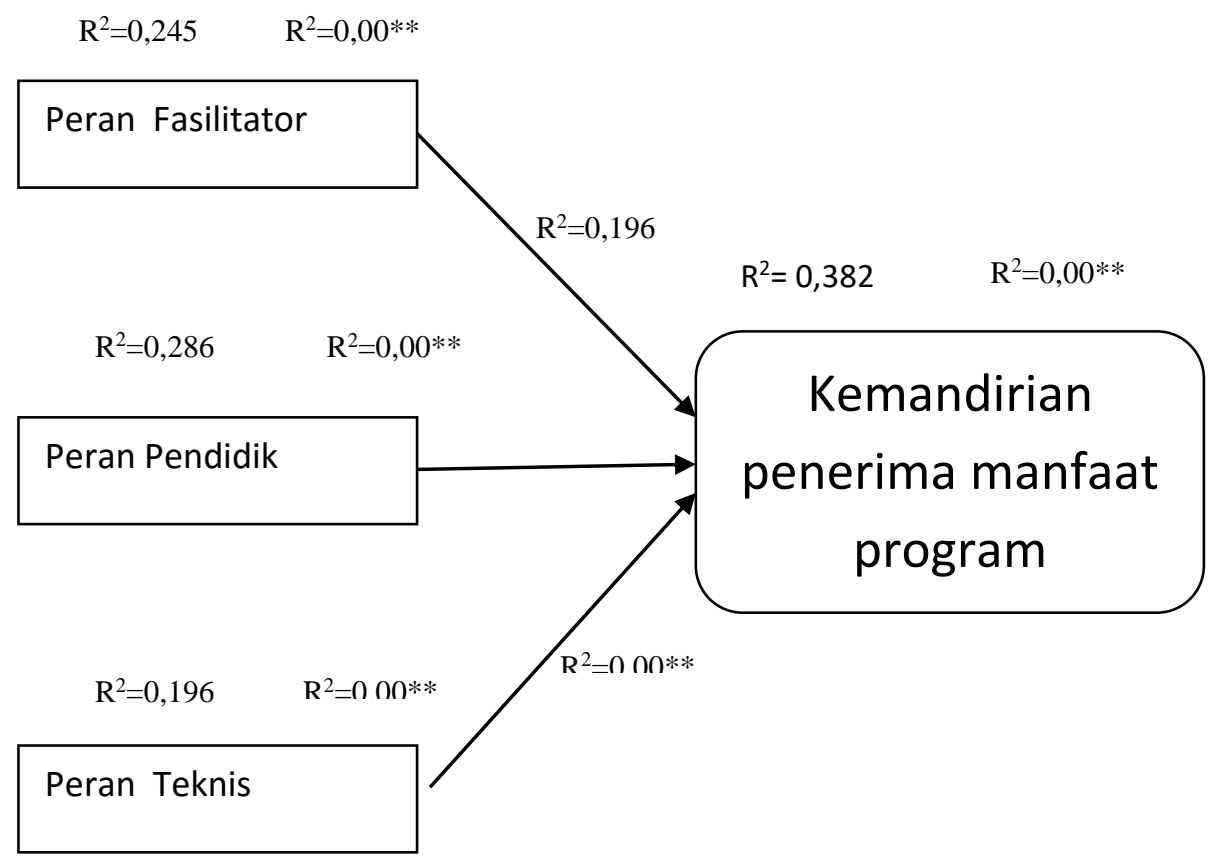

Gambar 1. Analisis Pengaruh Peran Lembaga Karya Masyarakat Mandiri Terhadap Kemandirian Penerima Manfaat Program.

\section{KESIMPULAN}

Kesimpulan dari hasil penelitian ini bahwa Lembaga Karya Masyarakat Mandiri Dhompet Dhuafa telah melakukan kegiatan pemberdayaan ekonomi produktif yang dilaksanakan di Kabupaten Cianjur. Karya Masyarakat Mandiri sejak tahun 2012. Selanjutnya dilakukan merger pada tahun 2016 antara Pertanian Sehat Indonesia (PSI), Kampoeng Ternak Nusantara (KTN) dan Karya Masyarakat Mandiri dengan tetap menggunakan nama Karya Masyarakat Mandiri (KMM). KMM merupakan organ PT CE Dompet Dhuafa dalam pengembangan program-program ekonomi komunitas melalui aktifitas pemberdayaan masyarakat. Jenis Program yakni pertanian, peternakan, UMKM, Pesisir dan Nelayan serta CSR. Untuk lokasi dan pragram dari Karya Masyarakat Mandiri yang diteliti adalah program Lumbung Desa di Desa Cibeber Cianjur berjumlah 200 Kepala Keluarga Cianjur dan Program Green Horti Mustahik Move To Muzakki di Desa Sindanglaya Cipanas Cianjur (M3) berjumlah 30 Kepala Keluarga.

Hasil dari penelitian ini bahwa Peran Lembaga Karya Masyarakat Mandiri (peran fasilitator, peran pendidik dan peran teknis) terhadap perubahan perilaku hampir mendekati $40 \%$. Hal ini ditunjukkan dengan hasil SPSS koefisien determinasi (R²) sebesar 0,382 . Pengaruh ini sangat nyata (signifikan) yang ditunjukkan dengan probabilitas $0,00 * *$. Peran Lembaga Karyawan Masyarakat Mandiri memiliki kontribusi yang cukup tinggi pada perubahan perilaku karena mereka merasa bahwa peran fasilitator, pendidik, dan teknis telah memberikan pengaruh melalui pengetahuan, sikap dan keterampilan

Adapun rekomendasi dari penelitian ini sebagai berikut;

1) Lembaga Karya Masyarakat Mandiri dapat melakukan fasilitasi yang intens dalam kegiatan promosi dan pemasaran untuk produk yang dihasilkan oleh petani terutama sayuran organik yang dihasilkan oleh penerima manfaat Program Green Horti Mustahik Move To Muzakki di Desa Sindanglaya Cipanas Cianjur. 
2) Penguatan kelembagaan perlu dilakukan secara berkelanjutan dari segi kepemimpinan, sarana dan prasarana serta jejaring kerjasama dengan berbagai pihak.

3) Penguatan semangat gotong royong dan kebersamaan antara penerima manfaat program dalam rangka menyukseskan program tersebut.

\section{DAFTAR PUSTAKA}

\section{Buku}

Hasan, Muhammad, Manajemen Zakat Model Pengelolaan yang Efektif, Yogyakarta: Idea Press, 2011.

Lord, John. Hutchison, peggy. 1993. The process of empowewrment: implication for theory and practice. 12:1ij.

Ife, J. dan Toseriero, F. 2008. Community Development: Alternatif Pengembangan Masyarakat di Era Globalisasi. Yogyakarta: Pustaka Pelajar.

Mustafa Edwin Nasution, 2005 Zakat sebagai instrument pengentasan kemiskinan di era otonomi daerah, Proceedings of International seminar on Islamic Economics as a Solution, Medan: IAEI,

Nasution, dkk. 2008. Indonesia Zakat and Development Report 2009. Depok: CID.

Prijono dan A.M,W Pranarka (eds). 1996. Pemberdayaan: Konsep, Kebijakan dan Iimplementasi.. Jakarta:CSIS.

Suparjan, HempriSuyatna. 2003, Pengembangan Masyarakat dari Pembangunan sampai Pemberdayaan.Yogyakarta:Aditya Media

Sumaryadi, I Nyoman. 2005, Perencanaan Pembangunan Daerah Otonom dan Pemberdayaan Masyarakat. Jakarta: Penerbit Citra Utama.

Singarimbun, Masri dan Sofian Effendi. 2006. Metode Penelitian Survai, Jakarta: Pustaka LP3ES, 2006

Susanto, Ahmad. 2018. Bimbingan dan Konseling di Sekolah Konsep, Teori, dan Aplikasinya. Jakarta: Prenadamedia Group.

\section{Jurnal}

Rachmiwanti, Vira dan Hartosujono. 2015. Hubungan Antara Dukungan Sosial dengan Kemandirian Pada Penyandang Tuna Daksa di Pusat Rehabilitasi Terpadu Penyandang Cacat Bantul. Jurnal Spirit. Volume 5. Nomor 2.

Utami, H.N. 2007. Keberdayaan, Kemajuan, dan Keberlanjutan Usaha Pengrajin: Kasus Kabupaten Sidoarjo dan Kabupaten Magetan Provinsi Jawa Timur. (Disertasi). Bogor (ID): Sekolah Pascasarjana IPB. 